\title{
INTOXICAÇÃO POR MACONHA. Traficante e Usuário
}

\author{
Antonio Augusto Machado de Campos Neto
}

\begin{abstract}
Resumo:
Em linha evolutiva, a partir de documentos a disciplinar a venda de substâncias medicinais e de medicamentus. mesclada à criação da Policia Sanitária do Império, Regimento de 29 de setembro de $185 \mathrm{l}$, até a mais importante das leis da legislação moderna, Lei n. 5.726, de 29 de outubro de 1971, junto à Lei n. 6.368, de 21 de outubro de 1976, consagrada por projuto aprovado pelo Congresso Nacional, a matíria visa os efeitos da maconha, passando pelos seríssimos casos sobre a intoxicação desta planta, semelhante ao arbusto, que em épocas remotas foi aclamada como divina.
\end{abstract}

Palavras-chave: Efeitos da maconha. Fases descritivas. Vias de absorção. Legislação. Usuário e traficante. Legalização.

\begin{abstract}
:
In evolutive line. from documents to discipline the sell of medicinal substances and medicines, together with the creation of the Public Health Police of the Empire, Rugiment of 29 th september 185I, until the most important of the laws of the modern legislation, Law n. 5.726, of 29 th october 1971, together with the Law $n$. 6.368 , of 21 th october 1976 , consecrated by project approved by the National Congress, this article aims at the effect of marijuana, passing for scrious cases on the poisoning of this plant, similar to a bush, that at remote times it was acclaimed as divine.
\end{abstract}

Keywords: Effect of marijuana. Descriptive phases. Absorption ways. Legislation. User and dealer. Legalization.

$$
\begin{aligned}
& \text { "A Dose Faz o Veneno" } \\
& \text { (Paracelsus, 1493-1541) }
\end{aligned}
$$

1. Introdução. A origem e a expansão da planta

A Cannabis sativa. nome cientifico em consonância com a classificação de espécies realizada, em 1734, pelo professor de Botânica Carl Lineu, de Estocolmo, Suécia, é uma planta semelhante ao arbusto. O crescimento varia de cinco a sete metros de altura e é adaptável tanto às áreas desérticas quanto às tropicais, possuindo os gêncros macho e fêmea; há casos de hermafroditismo no mesmo tronco.

Bacharel em Direito pela Faculdade de Direito da I'niversidade de Säo Paulo. Jornalista e Editor da Revista da Faculdade de Direito da Universidade de São Paulo. Chefe do Serviço Técnico de Imprensa da Faculdade de Direito da Universidade de São Paulo. 
O pólen que fecunda a fêmea advém da flor do macho; após a fıccundação, a flor da fêmea é preenchida por sementes que garantem as futuras reproduçồs. Envelhecida. morte; todavia não-fecundada armazena energia extra, produzindo, assim, uma resina pastosa e pegajosa que contém múltiplas substâncias de diversas naturezas. Dentre essas substâncias está a Delta-9-Tetrahidrocanabinol, o THC.

A Cannabis agora protegida dessa resina tem a propriedade de se defender dos raios solares, desde o caule e suas ramificações, cuja concentração maior está na flor da fêmca. A maconha é essa flor protegida pela resina dos danos solares. Lim premissa final: o THC é um protetor solar.

Cumpre salientar que existe uma área na região cerebral do ser humano que tem a capacidade de receptor especial que se liga ao THC. Atí há pouco tumpo, curca de 15 anos, pesquisadores israelenses descobriram que a teoria da árca receptiva do cérebro do homem não possuía nenhum fundamento legal. Encabeçados pelo doutor Ralph Mechoulam, da Universidade de Tel Aviv, descobriram que o receptor serve exclusivamente para se ligar a outra molécula fabricada pelo próprio cércbro, batizando-a de anandamida.

A anandamida tem o controle de todos os sintomas imediatos. dentre eles os da sensação da fome, da histeria, do descontrole do tempo e das horas e até o do behaviorismo.

A Cannabis sativa teve origem no Cazaquistão, região da Ásia Central, sugundo a Organização das Naçõus Unidas, através de relatórios de 1999/2000.

O relatório, correspondente ao ano 2000 , ainda ressalta que as sementes são nutrientes, o caule tem a propriedade de fibras resistentes e a resina foi respaldo a estudos da Medicina Homeopática. As fibras são conhecidas como cânhamo, cujos vegetais são até hoje utilizados em confecção doméstica, tais como cordas e cordões e tccidos grosseiros.

O maiur problema trazido pela Cannabis é que ela assumiu especial importância. para assim se expressar em respcito a vícios. alćm do que se acredita ser hoje o mais difundido em todo o mundo.

No País, além de estar fazendo espantoso progresso, seu uso predomina em cigarros e cachimbos, ora pura, ora de mistura com tabaco e a terminologia utilizada para designar o produto, como também ocorre em outros países, apresenta-se bastante variada: maconha. diamba. riamba. liamba, birra, pango, dirijo, umburu, chico, chá de birra. atchi, erva, etc.

Na Índia é chamada de charas ou bangh e cultivada para a composição de diversas finalidades, até como calmante; no Marrocos de kif e na África do Sul, de dagga. 
O primciro contato registrado entre o homem e a maconha vem de um jarro de barro, com cerca de 12 mil anos de existência, encontrado no parque arqueológico de Yuan-shan, hoje Taiwan. O vaso apresentava o convivin com as marcas de corda impressas em cacos; as marcas de corda, segundo arqueólogos. provam que foram feitas com fibras de cânhamo. $\mathrm{E}$ isso demonstra que os antigos conheciam a Cannabis e a utilizavam em uso doméstico.

A planta trouxe também grandes benefícios no século XV: os primeiros livros, depois da Revolução da Imprensa, de Johann Gutenberg, foram impressos em papel de cânhamo, inclusive a Bibliu Sagrada.

Os gênios da pintura usavam telas de cânhamo e as caravelas da Antigüidade, que descobriram novos continentes c mares territoriais, eram impulsionadas ao vento por velas confeccionadas de cânhamo. A frota de Cristóvão Colombo. de 1496 , continha aproximadamente 100 toneladas da planta, compondo o velame. as cordas, as roupas c os mantos de cobertura para o frio.

$\mathrm{Na}$ China, a planta era cultivada para a extração da fibra com a finalidade de obtenção de produtos têxteis, desde o primeiro milênio da Era Cristã.

Em Londres. o Museu Britânico apresenta amostras de minúsculas tábuas de argila de escrita cuneiforme, nas quais estão detalhadas receitas médicas de origem assíria. E foram esses povos que criaram o nome da planta, chamando-a de kunubu, passando de geração a geração e de povos a povos; do árabe kinab ao grego kannabis. E [inalmente ao latim: Cannabis sativa, cuja tradução significa planta cultivada.

Os egípcios, comprovadamente o povo mais evoluído no desenrolar da História da Humanidade, conheciam a planta. Do contato com os gregos, delegaram seus conhecimentos para a Medicina Homeopática. O médico grego Galeno (século Il d.C.) utilizava as sementes da Cannahis sativa para combater a flatulência c o suco para o controle da dor-de-ouvido.

O uso de maior eslatistica da Cannabis sativa foi o da Arábia. A planta era consumida pelos xeques que a consideravam divina. Não permitiam o seu uso a qualquer cidadão, uma vez que seus "efeitos divinos" só poderiam ser sentidos por pessoas de alta capacidade intelectual. A erva era chamada de hashish que, hoje em dia. se trata da resina extraída da planta após estar ressicada.

Na época das três Cruzadas, conflitos religiosos que permanecem até hoje. tendo marcado com sangue o solo sagrado do Oriente Midio, em batalhas pela Terra Sagrada, milhares de homens foram eliminados de maneira violenta. Os conflitos envolveram francos, templários, hospitalários e ingleses. 
Há uma peculiaridade na Segunda Cruzada: Nur al-Din, sultão muçulmano Iutava pela defesa de Damasco, cuja posse era pleiteada pelo rei Luís VII, auxiliado pelo príncipe Reinaldo. Nur al-Din percebendo a derrota nomcou seu melhor oficial, o famoso Saladino que pertencia a uma falange intitulada "assassinos" que vem de "haxixc" "maconha" Por quê eles teriam essa titulação? Porque matavam sob o efeito de drogas, sendo a preferida a Cannabis saiva.

Saladino derrotou os cruzados enfrentando o rei franco Guy Lasignant e até u réi inglês Ricardo I na batalha de Hattin nas cercanias de Tiro e de Jerusalém. Ele é o herói mais adorado do inundo árabe em prol da unificação do Império muçulmano e pela retomada da Terra Sagrada que havia sido subtraida pelos cristãos há 88 anos, após a Primeira Cruzada.

Mérito do fato: a planta presente em batalhas nos 200 anos de conflito entre cristãos, que empunhavam em seu estandarte a cruz que continha o relicário com os fragmentos de Cristo, e os robustos exércitos da Jihad. Estes, para matar se beneficiavam dos efeitos da maconha; com certeza, pelos sintomas de autoconfiança que a planta oferece aos usuários.

A maconha e suas variedades como o haxixe e a marijuana eram usados em ciclos fechados no Oriente. Já no Ocidente, até o século XIX, permaneceu como curiosidade, não-só a maconha como o peyote, o paricá e o curare. compondo exemplos significativos de substâncias tóxicas que em épocas distintas sempre causaram a curiosidade, a preocupação e a eclosão violenta e inesperada.

A expansão da maconha entre os europeus veio com a invasão das tropas de Napoleão Bonapartc, em 1798, no Egito. A disseminação c o seu uso entre os soldados foi tão grande que os generais franceses trataram de proibir o consumo da erva. Os egipcios simplısmente ignoraram a proibição. E de nada adiantaram as medidas coercitivas e até judiciárias, acarrctando críticas arrasadoras de soldados a generais, algumas dando margem a conflitos c ameaças.

Nos mesmos moldes aconteceu na Inglaterra, com a ocupação do Exército inglès na Índia, colonizada em 1880. Os missionários anglicanos começaram a se tornar curiosos e até incomodados com o hábito indiano de beber bhang, nome dado à maconha. O contato com a planta foi imediatamente aderido pelos soldados do Comando Imperialista Britânico. Todavia, trataram de analisá-la por meio das características botânicas da planta e pelo uso doméstico dos povos indianos. Us nativos daquela regiâo usavam-na como efeitos afrodisiaco e analgésico. O resultado é o registro em dezcnas de artigos sobre o emprego terapêutico da maconha nas diversas revistas médicas inglesas, entre os anos de 1841 e 1901. 
No México, os índios a usavam em rituais; de início, o cacto chamado peyote e. em seguida, a maconha, chamada de "rosu muria" ou "mariazinhu"

O primeiro registro da Cunnabis no Novo Mundo é datado de 1545, quando os espanhóis a introduziram e a cultivaram no Chile. No Brasil, a maconha chegou com os escravos africanos de Angola, em 1549, trazidos pelos portugueses. Eles a infiltraram no meio do plantio nordestino da cana-de-açúcar. Clareiras eram abertas nos canaviais aos olhos dos sinhores-de-engenho que, curiosamente, ignoravam o seu cultivo. A plantaçăo era chamada de fumo-dc-angola ou pango que, com o passar dos tempos, foi chegando ao Sul do País, trazida pelos plantadores escravos que se proliferavam pelo território brasileiro. Já os fazendeiros do Sudeste e do Sul, ao contrário, trataram de proibir o seu consumo. Com a proibição, os escravos fumavam a maconha às escondidas, utilizando um pequeno cachimbo intitulado maricas que, atualmente, é a versão do narguilé oriental.

No livro Escravos nos Anúncios de Jornais Brasileiros do Século XIX, de autoria do sociólogo Gilberto Freyre, há relatos da comprovação do uso da planta pelos escravos africanos em rituais religiosos e como remédio:

Pulo menos é o que contam negros velhos: que às vezes se misturava maconha ao tabaco. Os negros trouxeram a maconha para o Brasil e aqui cultivaram como planta meio mística. para ser fumada em candomblés e xangôs, pelos babalorixás e pelos seus filhos. Também como planta afrodisiaca.'

\section{Os efeitos da maconha}

Não há nada de novidadeiro sobre os efeitos do 'letrahidrocanabinol ou princípio ativo da maconha que influenciam o físico humano, parafrascando Paracelsus, nome vulgar do médico c químico suiço Philippus Aureolus Thcophrastus Bombastus von Hohenheim que nos ensinava que "a dose faz o veneno"

\footnotetext{
A história da relaçào entre a Humanıdade e as drogas é muito extensa. com vasta bibliogralia e interessante aos estudiosos de Direito/Mcdicina, além de nos oferecer a percepção contemporânea com sociedades do mundo inteiro. Sào documentos infindáveis mas alguns pelo menos têm de ser recomendados como o do cientista politico Thiago Moreira de Souza Rodrigues em "Politica e Drogas nos Américas" que narra a história da proibiçăo das drogas, com ènfase à maconha. nos EUA e de como houve a repercussão na América Latina. incluso México, Colômbia e Brasil. Complemento com o historiador Henrique Cameiro que oferece um capitulo especifico sobre a maconha em seu livro "Amores e Sonhos da Flora: afrodisiacos e alucinógenos na botânica e na farmácia" Em 1986, surgiu nas livrarias paulistanas a primeira coletânea de trabalhos sohre a Cannabis sativa. incluindo tratados médicos do início do século $X X$. intitulado "Diamba Sarabamba". Nessa coletânea. um relato sobre a violência da ditadura brusileira contra os indio do Maranhão que plantavam maconha.
} 
Autoridades do mundo inteiro afirmam a inoqüidade de determinados prudutos que contêm a maconha, além da descrição minuciosa de intoxicação aguda e crônica, o que é confirmada por especialistas. incluso religiosos holandeses que há dícadas vêm pesquisando os seus efeitus psicotrópicos e psicoativos.

Os cfeitos têm como perfil as características apresentadas pela quantidade deste material psicoativo e a natureza da planta, isto é, a região do cultivo somada ao meio utilizado à sua preparação. Os sintomas dependem da quantidade da porção e do tipo de personalidade do usuário. E, por último, as manifestações clínicas que su dividem em sintomas imediatos; intoxicação aguda c crônica e, finalmente, a dependência.

As manifestações de sintomas imediatos têm um quadro sui generis perante a maioria dos usuários. Fim escala evolutiva: euforia; alteração sensoperceptivel; haixo senso de identidade e da realidade e alucinações visual e auditiva.

A intoxicação aguda tem como perfil. dada a ingestão alta. a despersonalização, inquietude, ilusões e delírios. E em alguns casus excitação e ataxia: este último quadro clínico é raríssimo, todavia não-desprezível.'

A intoxicação crônica, dado o uso prolongado e de grande quantidade, a bronquite, semclhante a do tabagismo, a uveite que é a inflamação da úvea, o conjunto formado pula coróide, íris e processos ciliares; descontrole psicomotor, além do rebaixamento cognitivo, isto é, o descontrole do conhecimento em si e da própria linguagem e total apatia ao universo em geral, sem nenhum objetivo pessoal e impessoal.

A dependência, quando do uso crônico, regular ou periódico, é desenvolvida pela total tolerância de altas doses: como o caso do tabagismo, cujo usuário chega a se intoxicar cum mais de dois maços de cigarro.

O professor Pedro Vicolau Gonçalves Samıos Rosado, da Faculdade de Medicina e Cirurgia do Pará. em tese de cátedra deféndida em 1954, intinulada "Estudo dos distúrbios nervosos produzidos pelo uso da maconha" obra editada pelo Serviço Nacional de Educação Sanitária do Rio de Janeiro. em 1958, chega às seguintes conclusões: "nas intoxicações de grau leve, intoxicação aguda. predominam os sintomas de natureza neurovegetativa, ao passo que, nas intoxicações médias e severas, preponderam os sintomas decorrentes do comprometimento do sistema nervoso cerebrospinal. Os sintomas de natureza neurovegetativa observados são: palidez e rubor da face, congestào das conjuntivas, estreitamento da fenda palpebral, midriase, horripilação e alteração da frequiência do pulso. Os sintomas de natureza cerebrospinal observados são os seguintes; náuseas $e$ vômitos, alteraçòes do ritmo respiratório, impressão de aumento da força muscular, sensação de leveza do corpo de flutuação, deambulação. euforia, caráter sucessivo das crises, exagero da sensaçào do tempo. perturbações sensitivas e sensoriais (insensibilidade ao frio, aumento da acuidade auditiva, etc.), exacerbação do apetite, logorréia e fuga de idéias, atenção saltuária e diminuida, enfraquecimento da vontade, sugestibilidade, impulsões que levan a agressões e atos criminosos, hipomnésia de fixação dupla consciência. delírio. ilusões, alucinações audirivas. visuais e cenestésicas e sono 


\section{As fases descritivas}

A respeito da etiologia da dependência a drogas, interessante e minucioso é o livro do especialista Emilio Federico Pablo Bonnet, ex-professor de Medicina Legal da Faculdade de Direito de Buenos Aires e ex-médico forense da Justiça Nacional da Argentina. Segundo Pablo Bonnet, in Medicina Legal, na intoxicação aguda tem-se:

a. fase eufórica

Inicia-sc por meio de sinais físicos que apresentam a congestão conjuntival; sudorese abundante: taquicardia; náusea/vômito; midríase; aumento de apetite e crioestesia das extremidades.

A segunda etapa é a dos sintomas psíquicos que apresenta a sensação de bem-estar; euforia expansiva; hiperacusia. tendência a se isolar em local silencioso: hipersensibilidade visual, que é o uso permanente e desnecessário de óculos escuros: exaltação erótica e a preservação da crítica e da lucidez.

b. fase confusional

Notifica-se pelas manilestações neurológicas que é traduzida como a marcha ebriosa sem ataxia.

Em seguida, os sintomas psíquicos:

Desorientação têmporo-espacial;

Perda da noção de tempo e de espaço;

Lentidão ideativa, com atraso no entender e no exicutar;

Hipersensibilidade sonora e cromática; ilusões;

Alucinações oniróides;

Imagens fantasmagóricas e audição de fonemas;

Deformação subjetiva da imagem corporal;

Crises de riso imotivado, semelhante à embriaguez.

Reações delirantes, do tipo paranóide, acompanhado de pânico.

c. fase de êxtase

É compreendida pelo chamado estado crepuscular:

- Acalmia geral;

- Tranqüilidade, sono e êxtase;

- Deformação subjetiva da imagem corpórea. 
d. fase final

É caracterizada pelo sono e despertar:

Sono profundo;

Despertar com lembranças agradáveis das vivências confusas da êxtase;

Sequidão na boca, acarretando a ingestão de litros de água;

Anorexia;

Cefaléia e repetição do uso da droga para voltar às primeiras sensações mencionadas acima.

O professor Emilio Bonnet apresenta em sua exposição de motivos a intoxicação crônica composta de sinais físicos e sintomas psíquicos:

Sinais Físicos:

anorexia, emagrecimento; caquexia progressiva. Conjuntivite crônica e congestão conjuntival. Bronquite catarral crônica, própria do fumante. Gastrite crônica e câimbras; e dores polineuríticas. por avitaminose.

Sintomas Psíquicos:

Síndrome "esquizoparanóide" que se traduz pela perda do pragmatismo estado catatônico; puerilidade; euforia imotivada;

Sindrome confusional simples ou onírico;

Sindrome depressiva:

Síndrome delirante alucinatória correspondente à audição e à visão.

Segundo a Organização Mundial da Saúde (OMS), a toxicomania é um estado de intoxicação periódico ou crônico, nocivo ao indivíduo e à socicdade, pelo consumo repetido de uma droga natural ou sintética.

A toxicomania se apresenta com as seguintes caracteristicas:

- Invencível desejo ou necessidade de continuar a consumir a droga e de procurá-la por todos os meios;

- Tendência a aumentar a dose gradativamente:

- Dependência de ordem psiquica ou física em face a seus efeitos.

Cumpre salientar que o elemento primordial nessa definição da toxicomania e do estado de intoxicação é o da nocividade individual e social, em consonância com o 
saudoso doutor João Bernardino Gonzaga, ex-professor titular de Direito Penal da Faculdade de Direito da Universidade de São Paulo. É o traço distintivo em relação ao uso de outras substâncias como a maconha è o álcool.

Fim consonância com a OMS, a intoxicação por (annabis sativa é reconhecida tanto pelo abuso quanto pela dependência, sendo inclusa em tabela de classificação internacional. O quadro classificatório é a da divisão de n. 304.2.

Divisão 304.2: Dependência de drogas.

Estado psiquico e por vezes também fisico, resultante de uso de uma droga, curacterizado por reações de comportamento que sempre incluem uma compulsâo para usá-la de modo continuo ou periódico, a fim de experimentar seus efeitos psiquicos e. por vezes, evitar o desconforto de sua falta. A tolerância à mesma pode ou-não estar presente. Acrescente-se que uma pessoa pode apresentar dependência de mais de uma droga.

I: a Divisão 305.20 aborda a intoxicação por maconha. na página de n. 157:

As características essenciais são sintomas psicológicos e fisicos especificos e efeitos desadaptativos comportamentais devido ao uso recente da ('annabis. Os sintomas psiquicos incluem euforia, intensificação subjetiva das percepções. sensação de lentificação do tempo (cerca de cinco minutos para uma hora). preocupação com os estimulos auditivo e visual. além da apatia. A euforia pode ser expressa por marcante senso de bem-estar e relaxamento. $O$ individuo pode se tornar indiferente ao seu meio. A taquicardia está invariavelmente presente, embora menos proeminente do que nos usuários crônicos. Congestão conjuntiva ustá quase sempre presente.

Outros sintomas fisicos incluem o aumento do apetite. dando preferência a guloseina e boca seca. lifeitos comportamentais maladaptativos incluem ideação paranóide, acıssos de pânico e de afetividade disfórica. $O$ usuário pode acreditar que ustá morrendo ou enlouquecundo. Alguns analistas pensam que estas ruações adversas ocorrem mais $\mathrm{em}$ personalidades rigidas. em pussoas que jả tiveram perturbação psicótica ou em circunstâncias consideradas ameaçadoras como, por exemplo, "batida policial" Outros efeitos maladaptativos comportamentais incluem comprometimento do julgamento e interlerência na atuação social ou profissional. 
4. As vias de absorção

Nesta assertiva, mister se faz relatar o modo de como a Cannahis sativa é usada, uma vez a absorção e a ação dos princípios psicoativos da droga sobre o organismo humano depender da via de administração.

Assim o Tetrahidrocanabinol é três vezes maior quando fumado do que quando consumido. O THC é absorvido com muito mais eliciência nos pulmões em parâmetro com o aparelho digestivo, porque a superficie dos alvéolos pulmonarcs é revestida de lipoproteina que, por sua vez, facilita a absorção de substância solúvel em gordura como o THC.

A Cannahis sativa dilata os brônquios de início; prolongado o seu uso provoca bronquite e asma, faringite e sinusite. O potencial carcinogênico da fumaça é o mais terrivel comparado com o do cigarro: a da maconha contém carabinóides e a do tabaco, nicotina. Possui $50 \%$ a mais de alcatrão e outros hidrocarbonatos carcinogênicos na fumaça da maconha em comparação com a do cigarro de tabaco.

O THC age no cérebro, uma vez ser transportado pelo sangue, e é a dosagem plasmática da maconha que fornece a quantidade da substância que está atuando no sistema nervoso central. Himbora haja correlação entre os níveis sangüíncos do THC e seus efeitos clínico, físico e psicológico não é sempre que essa quantidade reflete com exatidão os teores da substância no cérebro.

Ao usuário da maconha, recomenda-se nunca injetá-la na veia, uma vez. alguns preferirem para o deleite, porque a pressão pode abaixar abruptamente, chegando, inclusive, a zero; acarretando, assim, o choque clínico. E ainda poderá advir o mais terrivel dos problemas que é o do desastre mecânico, representado pela introdução de partículas macroscópicas na conente sangüinea, levando-o a embolias.

U sistcma neuromuscular torna-sc completamente frágil; sendo, assim, o usuário apresenta em seu estado clínico muita dificuldade em manter firmes as mãos e o equilíbrio corporal.

Com relação aos olhos, estes tendem a se tornar avermelhados. As pupilas não se alteram; todavia a pressão do liquido intra-ocular diminui. A maioria dos usuários recorre aos colirios e muitos tornam-se dependentes deste auxílio ocular, compondo um contingente significativo de consumidores em drogarias e farmácias.

Na relação sexual. a maconha desperta aumento do apetite sexual; todavia, aos homens requer mais cuidados em seu uso prolongado, porque diminui sensivelmente a quantidade de espermatozóides, alterando, assim, a fertilidade. 
('umpre salientar que embora haja casos raros, os espermatozóides deixam de sur produzidos. Complementando, a maconha atua no aparelho sexual, provocando também uma redução no tamanho e no peso da próstata e dos testículos, necessitando o usuário de tratamento sério e prolongado.

\section{Legislação}

No Brasil, o primeiro documento a disciplinar a venda de substâncias medicinais e de medicamentos, além de criar a Polícia Sanitária do lmpério, foi o Regulamento de 29 de setembro de 1851, uma vez o Código Criminal do Império não ter abordado esse tema. A Cannabis sativa era considerada uma substância para medicamentos.

O Código Civil, de 1890, estabelece sanção para o ato de "expor à venda ou ministrar substâncias venenosas sem legitima autorização e sem as formalidades previstas nos regulamentos sanitários"

A partir de 1921, surgem estatutos penais como o Decreto n. 4.294; o Decreto n. 20.390, de 1932. o Decreto n. 24.505, de 1934; o Decreto n. 780, de 1936, que foi modificado pelo Decreto n. 2.953, de 1938.

Em 25 de novembro de 1938, surge o Decreto-Lei n. 891 que é apontado como a fonte básica da Legislação Sobre Entorpecentes.

O Código Penal, de 1940, institui o delito de tráfico e uso ilícito de tóxicos no art. 281; a Cannabis sativa estava incluida pela sua toxicidade. Em 1964, a Lei n. 4.451 altera o art. 281 do Código Penal, acrescentando ao tipo a ação de plantar.

Em 1961, realiza-se a Convenção Única sobre Entorpecentes, extraindo-se dela uma lei interna, promulgada em 1964, sendo essa Convenção a que aprimora e apresenta a primeira lista extensa de substâncias entorpecentes ou causadoras de dependência. Dada a sua eficácia. serve de parâmetro às portarias do Ministério da Saúde do nosso País.

Em 1967, surge o Decreto-Lei n. 159, de 10 de fevereiro, tendo suma importância ao Direito Penal brasileiro, uma vez equiparar as substâncias causadoras de dependências física ou psíquica das entorpecentes, com a finalidade de âmbito penal e fiscalização, além do controle sobre o seu uso.

A mais importante das leis da legislação moderna é a Lei n. 5.726, de 29 de outubro de 1971, porque cuida literalmente do assunto e focaliza, com precisão, a prevenção ao tráfico e ao uso ilícito de entorpecentes, além de fixar medidas corretas para o tratamento e recuperação aos viciados. 
A legislação atual é a do projeto aprovado pelo Congresso Nacional e sancionado pelo presidente da República em 21 de outubro de 1976: a Lei n. 6.368.

Cumpre salientar que o anteprojeto toi estudado e elaborado por um grupo que apresentou um trabalho minucioso. composto por nomes afamados da sociedade brasileira: o magistrado doutor João de Deus Lacerda Menna Barreto, o psiquiatra doutor Oswald Moraes de Andrade, na presidência: o professor titular Paulu Ladeira de Carvalho e o médico Décio dos Santos Vives.

Em um cômputo geral da legislação, a L cui n. 6.368 dispõe sobre as medidas de prevenção e repressão ao tráfico ilícito e ao uso indevido de substâncias entorpecentes ou que determinem dependências física ou psíquica, dando, inclusive. outras providências.

$\mathrm{O}$ art. scgundo é enfático:

Ficam proibidos em todo o território brasileiro o plantio, a cultura e a exploração, por particulares, de todas as plantas das quais possa ser extraida substancia entorpecente ou que determine dependências fisica ou psiquica.

Parágrafo Primeiro - As plantas dessa natureza nativas ou cultivadas, existentes no tcrritório nacional. scrào destruidas pelas autoridades policiais, ressalvados os casos previstos no parágrafo seguinte.

Parágrafo Segundo. A cultura dessas plantas com fins tcrapêuticos ou cientificos só será permitida mediante prévia autorização das autoridades competentes.

A Lei n. 8.257, de 26 de novembro de 1991, e o Decreto n. 577, de 24 de junho de 1992. dispõem sobre a expropriação de glebas, nas quais se localizem culturas ilegais de plantas psicotrópicas.

O Decreto n. 78.992, de 21 de dezembro de 1976, regulamenta a Lei n. 6.368, de 21.10.1976.

A Constituição Federal, de 1988. no Título IX, Das Disposições Gerais, em seu art. 243, reza:

As glebas de qualyuer regiãu do Pais, onde forem localizadas culturas ilegais de plantas psicotrópicas serão imediatamente expropriadas e especificamente destinadas ao assentamento de colonos. para o cultivo de produtos alimentícios 2 medicamentosos. sem qualquer indenização ao proprietário e sem prejuizo de outras sanções previstas em lei.

O Decreto n. 54.216, de 27 de agosto de 1964, promulga a convenção Ĺlnica sobre Entorpecentes e inclui a Cannabis sativa na primeira c na quarta das yuatro Listas 
de Entorpecentes, tanto a Cannabis quanto a sua resina. Após o Preâmbulo, em seu art. primeiro dá as seguintes definições:

\section{Artigo Primciro \\ Definições}

1. Salvo indicação expressa em contrário, ou onde o contexto exigir outra interpretação. as seguintes definições serão aplicadas na presente Convenção:

a) "Órgão" é o Órgão Internacional de ('ontrole de Entorpecentes.

b) O termo Cannahis designa as extremidades floridas ou com fruto da planta Cannabis, qualquer que seja o nome que tenham, das quais não foi extraida a resina $(\mathrm{com}$ exclusão das sementes e folhas não-unidas às extremidades).

c) "Planta de Camnabis" é toda planta do gênero camnabis.

d) "Resina de Cannabis" é a resina separada, em bruto ou p.rrificada, obtida da planta Cannahis.

O art. 28 dá ênfase à fiscalização:

Fiscalização da Cammabis

a) Sc uma Parte permite o cultivo da planta da Cannabis para a produção da Cannabis ou de sua resina, será aplicado a esse cultivo o mesmo sistema de fiscalização estabelecido no art. 23 para a fiscalização da dormideira.

b) A presente Convenção não se aplicará ao cultivo da planta de Cannabis destinada exclusivamente a fins industriais (fibra e semente) ou hortículos.

c) As Partes adotarão medidas necessárias para impedir o uso indevido e o tráfico ilicito das folhas da planta da Cannabis.

A maconha é classificada no quadro dos alucinógenos; sua letalidade é baixa e a precocidade (idade mídia do primciro uso, em anos) é de 18,6, segundo a Pesquisa Nacional Domiciliar sobru Abuso de Drogas dos Estados Unidos da América, de 2003. Em 2005, a idade média do primeiro uso, em anos, atinge 16,6!

O consumo cresce assustadoramente, cujos números chegam a 250 milhões da população mundial acima da idade acima especificada. Assim como Alexandre Dumas descreve as festas e orgias do século XIX regadas a vinho e maconha em $O$ Conde di 
Monte Cristo, publicado em 1845, as do século XX-XXI, com ênfase as de adolescentes. têm seguido esse perfil. haja vista as mais recentes intituladas Raves.

A volta propriamente dita da maconha se deve à moda da Geração-68, através dos jovens e dos hippics, contestadores que pregavam a filosofia "Paz $\mathrm{C}$ Amor" que se recusavam a lutar no Vietnã, que resistiam contra as ditaduras, que quase derrubaram governos em 1968. Reintroduziram-na à sociedade, foram grandes consumidores e até hojc é a geração que faz vista grossa aos saber que seus filhos fumam baseados.

A descriminalização da maconha foi aprovada em setembro de 2003 pelo Governo holandês. Todavia em coffee shops é vendida há mais de três décadas, desde 1975. com uma parafernália sofisticada, isto é, compra-se a maconha em máquinas eletrônicas, dando-se o luxo da escolha da droga pelo país de origem ou em balcôes de vidro transparente de perfeita nitidez, cujas amostras preenchem de alegria e êxtase os olhos de usuários. São coffee shops distribuidos pela cidade, desde a Central Station, um dos terminais do Aeroporto Internacional Skeepol, até distritos afastados como Leinzplein e famosos como o Bull Dog. ${ }^{3}$

Em Luxemburgo, a venda também é permitida. Na maioria dos paísesmembros da União Européia (UE) não há sanções a consumidores de pequena quantidade. A média de pequena quantidade é aproximada a 30/50 gramas, variando de Estado a Estado. O limite, por dia para o usuário, é o de 0,5 grama, com a intenção repressiva de se evitar o consumo abusivo.

Espanha, Grécia e Itália toleram o consumo de pequenas quantidades.

Em França se requer o cadastramento voluntário do usuário por meio de serviço social. Em Portugal o porte de drogas é um ato de infração administrativo.

A Inglaterra descriminalizou, mas se exige o cadastramento mesmo involuntário do usuário. Também na Inglaterra a legalização enveredou para a sintetização do THC que é comercializado como remédio intitulado Marinol.

O composto Marinol é indicado a tratamento de vômitos junto à diarréia provocados pela quimioterapia, além de estimulante ao apetite nos casos de anorexia e a pacientes terminais, auxiliando-os na recomposição do peso físico, uma vez o emagrecimento dos soropositivos ser muito acentuado.

O autor visitou nos anos 1999/2001/2002 Amsterdam e Roterdam. Holanda; Bruxelas, Bélgica. Luxemburgo. Capital, coffee shops yue têm internamente venda incrementada de Cannabis sativa, verificando in loco usos e costumes dos noclivagos europeus, diante do Direito consuetudinário que lhe são regidos. 
6. O Usuário e o Traficante

O usuário, quando portador de entorpecente, no caso a maconha, está tipificado no art. 16, da Lei n. 6.368, o qual pune a ação de adquirir, guardar ou trazer consigo, para uso próprio, substâncias entorpecentes ou que determine dependência física ou psíquica, sem autorização ou em desacordo com a determinação legal ou regulamentar.

A pena é de seis meses a dois anos de detenção e pagamento de 20 a 50 dias-multa. Observa-se que o dispositivo se aplica ao chamado experimentador primário. ao curioso, ao usuário eventual, ou mesmo ao viciado sem dependência. Sendo assim. por exclusão, pode-se dizer que o art. 16 pune o agente não-traficante e não-dependente, uma vez o traficante incidir nos arts. 12,13 e 14, e o dependente é isento de pena, desde que fiquem configuradas as demais exigências do art. 19 daquela lei.

Cumpre salientar que a posse de tóxico para uso próprio, sempre levando em consideração a maconha, foi considerada crime pelo Decreto-Lei n. 385, de 1968, para se evitar a constante impunidade dos infratores que, surpreendidos com esta substância, diziam-se meros usuários da Cannabis sativa.

Todavia, a Lei n. 5.726, de 29 de outubro de 1971, equiparou esta conduta ao tráfico, punindo as ações com a mesma pena, o que deduzo que o legislador, de 1976, tenha extrapolado o conceito de porte de tóxico para uso próprio como delito autônomo, fixando pena bem inferior às figuras relativas ao tráfico.

Há uma grande diferença em se portar alguns miligramas da erva, em parâmetro aos infratores que chegam a portar quilos e até toneladas, utilizando-se, inclusive, de transportc aéreo. Ou, ainda, a quem chegue a plantar em terreno de sua casa, própria ou alugada, mais de um arbusto, o que se faz chegar à conclusão de que aqueles pés de Carnabis venham a favorecer outros usuários.

Em suma, ao uso p:óprio, fixa-sc o dispositivo com a intenção de incriminar o usuário que adquire. guarda ou traz consigo a erva. Se a aquisição, guarda ou porte é para outrem, está tipificado o tráfico, e o agente cometerá o delito do art. 12 da I.ei n. 6.368 , de 21 de outubro de 1976.

O Decreto n. 78.992, de 21 de dezembro de 1976, que regulamenta a Lei $n$. 6.368 , dispõe sobrc medidas de prevenção e repressão do tráfico ilícito e uso indevido de substâncias entorpecentes ou que determincm dependência física ou psíquica. $\mathrm{O}$ art. primeiro ruza que é dever de toda pussoa física ou jurídica colaborar na prevenção e repressão do tráfico ilícito c uso indevido de substâncias entorpecente ou que determine dependência física ou psíquica. 
Os delitos definidos nos arts. 12 a 17 da Lei n. 6.368 consumam-se com a prática de uma ou mais ações contidas no respectivo tipo de delito. No caso do tráfico, a infração se configura integralmente com a venda do tóxico pelo agente a uma outra pessoa.

O viciado, em $70 \%$ de casos, é formado pela faixa etária dos $18 / 21$ anos, isto é, adolescentes que têm problemas de afirmação e conflitos psicológicos. Este adolescente é a presa mais fácil para o traficante; todavia, o mais sensivel à educação e à orientação. Acuso como obrigação do Estado e de sociedades de maneira ampla e irrestrita.

É inacreditável que haja discrepância com relação à propaganda educativa. Por quê? Porque muitos educadores são favoráveis; outros, salientam que a propaganda poderá gerar o interesse e a provocar efeito totalmente contrário: o da busca pela droga.

Em síntese, a opção correta é a da monopulização educacional realizada pelos Governos federal, estadual e municipal, dependendo, inclusive, de área urbanística de indice por população. Uma propaganda de maneira suave com perfil esclarecedor, tendo no elenco jovens atores profissionais, de boa formação que são encontrados em agências de propaganda e/ou emissoras de TV: possuindo, de preferência, a faixa etária de $18 / 30$ anos.

E propaganda pesquisada: aquela que mostra discernimento entre drogas leves e pesadas. Complemento, sempre sugerindo, cursos em todos os níveis da Educação, quais sejam, palestras em série devidamente coordenadas por educadores credenciados e habilitados a cada espécie de droga. Por fim, campanhas esporádicas. enfatizando as realizadas em meses de estação quente, primavera e verão, pois contam com os periodos de férias e Carnaval.

Frisamos que defendemos a monopolização educacional antitóxica pelos órgãos estatais especializados, de modo que os cursos, esclarecimentos gerais, palestras ou campanhas se realizem, tenham orientação única, oficial e ponderada.

Uma peculiaridade é digna de ser comentada: o traficante não possui o hábito de se drogar, em comparação ao uso próprio do viciado que, em desespero para obtenção da droga. freqüenta locais de alta periculosidade.

O saudoso professor de Direito Penal da Faculdade de Direito da Universidade de São Paulo, João Bernardino Gonzaga. do qual tive a honra de ter sido aluno, relata com precisão e equilíbrio, que:

das inúmeras pesquisas realizadas, a maconha possui toxicidade mais fraca do quc o ópio ou a cocaina e inferior, sob certos aspectos, até à do álcool. Como este, porém, é inegável que constitui seriissimo problema social. Pelas 
graves repercussões físicas e mentais que produz, transitoriamente, nas intoxicações agudas, ou como fator coadjuvante nos casos de habitualidade no consumo; pela faculdade com que arregimenta grandc númcro dc adeptos, assim alastrando-se enormemente o vício pela situação de instabilidade em que coloca o indivíduo, predispondo-o muitas vezes para o uso de outras drogas mais nocivas; pela sua aptidão geradora de comportamentos antisociais, seja por atuação direta sobre o psiquismo do seu consumidor, seja pelo ambiente deletério que cria em torno deste, seja ainda pelo conjunto de torpes atividades que cercam o comércio. E, assim, torna-se incontestável que o uso da maconha deve ser severamente reprimido.

\section{A planta que não deixa de ser remédio}

A Cannabis sativa não deixa de ser classificada como remédio que possui várias aplicações, dentre elas a de ter o poder de reduzir o sofrimento de muitos doentes. Todavia, com a proibição, o mundo inteiro a condenou, inclusa qualquer plantação destinada à destruição. ${ }^{+}$

Sendo assim, a partir do momento um que se decretou que usar a planta pelo efeito psicoativo é ilegítimo, todos os seus usos legítimos. como o de fazer papel, tecidos, combustivel, comida, remédio e outros foram tambím banidos.

Há dois grandes empecilhos para o uso medicinal da Cannabis sativa.

O primeiro é o fato de o THC, o princípio ativo da maconha, não ser solúvel em água. Absolutamente ele não o é, ao contrário de quase todas as substâncias farmacologicamente ativas. Dissolver em água é o procedimento normal e básico para se fazer um remédio. uma vez que, só depois, o princípio ativo é transformado em uma pastilha ou então injetado por meio de seringas, métodos de administração que têm a vantagem de garantir uma dose devidamente precisa.

O outro é o fato de a Cannabis sativa, como remédio, ter um inescapável efeito colateral. a saber: a maconha deixa o individuo totalmente fora do scu comportamento normal. Ou seja, exemplificando, se se tem um perfil de homem quieto, ocorre-se uma significativa alteração, tornando-se irrequieto; se inibido, desinibido.

A substância que provoca essas alterações, como vimos anteriormente, é a mesma que conforta na doença, o THC. Assim, não dá para discernir uma da outra. E,

Como referència bibliográfica é interessante se recorrer ao livro "Maconha", de autoria do ilustre deputado federal Fernando Gabeira. O parlamentar disserta de maneira equilibrada a legalização da maconha . enfatiza os "usos legitimos" da planta. 
para muitos pesquisadores e legisladores, é inaceitável que um remédio provoque alterações qualquer que seja a sua classificação.

Entende-se que esse segundo empecilho apresents um problema munor, em parâmetro à Medicina que aceiła efeitos colaterais bem mais complicados, como o do tratamento do câncer, que podem até matar. Porém, há de se aceitar que, por questões morais, muitas pessoas são contrárias a que se altere o estado de consciência de todo $\mathrm{e}$ qualquer ser humano.

\subsection{O hábito de uso da ('annabis sativa}

A maior quantidade do uso da Cannabis, em parâmetro à Amsturdã, livre, é a da ilha da Jamaica. Estima-se que $70 \%$ a $80 \%$ dos habitantes usam a erva em forma de cigarro ou de chá; este último, pelas mulheres e crianças. () chá é administrado como remédio para insônia e reumatismo. O baseado jamaicano é considurado oriundo de erva sagrada, vinda de Deus que é chamado de Jah pelos seguidores do rás Tafari Makonnen, imperador da Etiópia, coroado em 1930, os rastafáris. Não tem a forma de cigarros, como é de costume aos usuários do mundo inteiro, e sim a forma de cone chamado de spliff.

Até hoje em dia. em pleno século XXI, os homeopatas indianus têm o hábito de administrar a maconha como efeitos afrodisíaco (em alternativa, por exemplo, ao Viagra, Cialis e similares) e analgésico (em alternativa aos mais modernos da farmacologia, por excmplo, Doril, Dôrico e similares). O hábito é secular.

O clérigo inglês Robert Burton (1577-1640) foi quem pioneiramente reconheceu no Ocidente o uso da maconha para tratamento de depressão e assim foi classificado e catalogado, uma vez ter confirmado a assertiva no tratado de sua autoria Anatomy of Melancholy ("Anatomia da Melancolia"), de 1621.

No século XIX, o médico da Corte inglesa receitou maconha à Rainha Vitória para tratamento de cólicas menstruais. A vida da rainha maconheira coincide praticamente com a idade de ouro da Cannabis, justamente o periodo em que de $z$ cnas de artigos médicos recomendavam suas propriedades terapêuticas, conforme observado anteriormente.

No século XX, com o crescente uso de opiácı́os e graças à invenção da seringa hipodérmica e à descoberta dos barbitúricos e da aspirina, a Cannabis entrou em desuso como remédio. Foi extirpada da farmacopéia americana em 1941, da francesa em 1946 e acabou totalmente proibida em todo o mundo.

Mediante todos esses obstáculos, certos laboratórios farmacêuticos conseguiram desenvolver medicamentos para substituir a Cannabis sativa fumada, em 
tratamentos médicos. Cumpre salientar que o mais bem-sucedido é o Dronabinol, nome genérico do Marinol. Para realizá-lo, os cientistas do Unimed, laboratório norteamericano, dissolveram o THC em óleo e o colocaram numa cápsula gelatinosa. A dissolução em líquido oleaginoso tem a desvantagem de que é difícil discernir, com exatidão, a quantidade de THC em cada cápsula/unidade.

Mesmo assim, o Marinol tem tido excelentes resultados em várias doenças. Todavia, muitos pacientes acham que o seu efeito é bem mais desagradável que o da planta. Ao contrário da maconha, que tem dezenas de componentes com efeito farmacológico, o Marinol é puro THC. A premissa final: posiciona o paciente num marasmo total. isto é, sem vontade e disposição para realizar absolutamente nada.

Atualmente, existe outro remédio realizado por pesquisadores do Laboratório Eli Lilly, o Nabilone, comercialmınte conhecido como Cesamet. A pretensão dos pesquisadores daquele laboratório era a de desenvolver um análogo sintético do THC que não possuísse nenhum efeito psicoativo.

Cientistas confirmam que de fato o Cesamet realmente altera muito pouco a percepção. Mas os resultados médicos não conseguiram aprovação, deixando os pesquisadores desanimados e frustrados. E assim, a maconha continua sem atração alguma para os macrolaboratórios e muitos pacientes opinam que a melhor maneira de administrar o THC é realmente fumando maconha. Saliento que nem o Marinol nem o Cesamet conseguiram aprovação do Ministério da Saúde do Brasil.

8. As moléstias e doenças que podem ser tratadas com o THC. segundo pesquisas realizadas

a) Náusea: a maconha, cientificamente comprovada, diminui a náusea, principalmente às pessoas que estão sendo tratadas com quimioterapia que, por sua ve\%, provoca enjôos. Há vários remédios que reduzem o enjôo e são bastante eficazes, mas entre $10 \%$ e $20 \%$ dos pacientes simplesmente não respondem aos remédios legais e nessa mesma proporção respondem muito bem à maconha.

b) Aids: hoje em dia somos cientificados de que um soropositivo pode passar anos sem desenvolver a doença. Assim que as manifestações venham à tona, como a falta de apetite, o emagrecimento, a diarréia, a febre, fazendo-o perder cerca de $20 \%$ a $30 \%$ do peso normal em um mês, mais ou menos, sem se associar os fatores psicológicos, o problema está instalado na vida individual desse paciente. Sendo assim, a luta pela recuperação do peso é um dos primeiros cuidados a se tornar na vida desse cidadão. E é ai 
que a maconha entra gloriosamente. porque ela ofcrece um apetite voraz e nenhum remédio é tão eficiente para manter o peso dos portadores do HIV quanto a maconha.

c) Esclerose Múltipla: trata-se de uma doença degenerativa que ataca terrivelmente o sistema nervoso: provocam dores insuportáveis. furtes espasmos musculares, além da perda do controle da bexiga e do intestino. A má função do sistema imunológico faz com que as células de defesa destruam a mielina que é a camada gordurosa que envolve os tecidos nervosos. A maconha diminui os espasmos e alguns pacientes têm efeitos benéficos na redução da dor e no funcionamento dos órgãos. A conclusão de cientistas é a de que a maconha interfere favoravelmente no sistema imunológico, proporcionando confortabilidade aos portadores da Esclerose Múltipla.

d) Glaucoma: essa doença se caracteriza pelo aumento de pressão do líquido que fica dentro do olho, acarretando distorções na correta visão. O problema é que a pressão torna-se gradativamente alta e a longo prazo leva o seu portador à cegueira. Os laboratórios fabricam excelentes colírios para o tratamento do glaucoma, satisfazendo grande parte desses doentes. Todavia, alguns não conseguem resultados e isso é seriíssimo, porque o não-controle da pressão intra-ocular faz com que se perca a visão mais rápido. É sabido yue a maconha dilata os vasos sangüíneos dos olhos, deixando-os avermclhados e, assim, baixa a pressão intra-ocular. $O$ empecilho é que o paciente teria de fumar maconha pelo menos de quatro em quatro horas, tornando-sc nocivo à saúde esse método não-convencional.

e) Dor: à princípio não nos parece crivel, mas a Cannahis é um analgésico conhecido há milênios que só se tornou um fato esquecido e ignorado com a produção da Aspirina, no final do século XIX. A credulidade de fato é difícil de imediato, porque primeiro nem todos conhecem a história dos remédios: segundo, porque o cigarro lumado em demasia tem como um dos sintomas maiores a conhecida dor-de-cabeça. F. sempre se associa a maconha ao cigarro. A maconha é promissora no tratamento de dores difíceis de controlar de outra forma, como a das cólicas menstruais ou a da enxaqueca. O THC tem a desvantagum do efeito psicoativo como já vimos anteriormente; todavia, é bem menos tóxico que outras substâncias analgésicas, as quais geralmente são tidas como inofunsivas. Como parâmetro: a Aspirina chega a matar milhões de pessoas em todo o mundo, porque provoca irritação no estômago e úlceras que podem levar a uma hemorragia. O THC não possui em toda a sua história um único registro de morte.

f) Ansiedade: a Cannabis é estritamente leve contra a ansiedade. Todavia, varia de comportamento de pessoa para pessoa. porque todas as substâncias farmacologicamente ativas agem de maneira diferente em cada paciente. porém o THC parece ser especialmente sujeito a variações. Sendo assim, algumas pessoas melhoram 
após fumar a maconha; outras, principalmente as que pouco têm esse hábito. passam a obter cfeito oposto. O risco de tratar ansiedade com maconha é a dependência, porque ela se manifesta na maioria de pessoas excessivamente ansiosas.

9. Considerações finais e lı̣galização da maconha

a) $O$ uso alimentar da maconha.

Reporto-me ao uso alimentar: os usos lícitos da Cannabis, seguindo o Relatório da Organização das Nações Unidas (ONU), mister se faz relatar que o óleo da semente da maconha tem apenas $8 \%$ a $12 \%$ de gordura saturada, como parâmetro àquela da manteiga que causa aumento dos niveis de colesterol e pode levar ao enfarte.

$O$ restante gorduroso é monoinsaturado e poliinsaturado que reduzem o colesterol. Todavia existe equilibrio na quantidade dessas duas gorduras. E essa proporção é mais saudável que a maioria dos óleos disponíveis no mercado. $O$ azeite de oliva tem cerca de $16 \%$ de gordura saturada, o óleo de girassol tem 12\%. Somente o óleo de canola, tido como o mais saudável, tem indice de gordura saturada inferior, a saber, $7 \%$.

Cumpre salientar que além da produção de óleos, a semente tem muitos nutrientes e pode ser importante fornecedora de fibras e vitaminas, uma vez que os índices de THC são minúsculos e podem ser reduzidos ainda mais, selecionando variedades menos psicoativas.

Há séculos a semente da maconha é usada como alimentação a pássaros, com ênfase aos canários. Os animais a adoram e quando the são oferecidos grãos diversos misturados às sementes de maconha, tendem a consumi-las imediatamente, antes de encostar nos demais grãos.

E assim se observa o grande potencial inexplorado da maconha. E nada disso, realizado com cuidado, implicaria em aumento do uso da droga ou em dano à saúde pública; pelo contrário, a saúde pública ganharia com os novos produtos alimentares.

Em 1997, a União Européia já havia percebido o potencial econômico e industrial da planta e cultivava mais de 15 mil hectares de Cannabis legal em seu território. Nos EUA. berço da proibição da maconha, onze Estados aprovaram o seu uso médico. embora o Governo federal norte-americano considere essas iniciativas ilegais e continue investigando clínicas autorizadas a receitar maconha.

b) Pais \& filhos.

O prolessor Mauro Weintraub, da Faculdade de Medicina da Universidade de São Paulo. relata com muita propriedade em seu livro Sonhos e Sombras, a Realidade 
da Macunha que "a Cannabis sativa era fundamentalmente consumida pelas camadas menos privilegiadas da sociedade. Para a classe média e alta, maconha era 'coisa de gente pobre' e a delegacia policial. local mais adequado para tratar do assunto"

Com o passar dos anos, a Cannabis foi ganhando adeptos entre os filhos das classes mais abastadas, dando margem a modificações de opinião dessas parcelas da sociedade. Sendo assim, a indiferença se transformou em apreensão e em muitos casos em alarme.

Existem pesquisas que comprovam que hoje em dia a convivência entre ricos e pobres é cada vez mais acentuada, porque têm preferência pelos mesmos hábitos (usos e costumes), no caso o de fumar a maconha. Dessa convivência, diálogos cresceram entre jovens de elite com os de classe menos favorecida. Ressalto que estes últimos têm-se aproximado e compartilhado, dada a proteção que recebem dos mais ricos, em festas noturnas das grandes metrópoles.

O psiquiatra e psicofarmacologista Mauro Weintraub ainda observa que:

ao mesmo tempo, passou a ficar cada vez mais dificil defender a posição de que a maconha e crime são indissoluvilmente ligados, quanto mais não fosse pela relutância em se considerar membros da própria familia como criminosos em potencial... Em decorrência disso, se a ligação entre uma coisa e outra não desapareceu por completo do pensamento das pessoas, ao menos se tornou mais distante, possibilitando, inclusive. o surgimento de movimentos em prol da descriminalização da maconha, acompanhando o que acontece em muitos países em que a droga se tornou endêmica intre a juventude.

Cabe citar que os jovens pela própria natureza têm uma tendência de querer modificar o modo como se sentem, e o caminho a consegui-lo é o de se deixar absorver por alguma atividade, a qual, por si só, propicie em não-conseguir pensar em outra coisa. Semelhante ao nihilismo, ao nada, ao estado de espírito alheio a tudo o que se passa ao redor.

E nessc comportamento, o hábito de fumar maconha como, também, o de manipular jogos eletrônicos que têm algo de muito importante em comum. Sendo assim, não é mera coincidência que muitas casas de jogos elctrônicos, como fliperamas, servem de pontos de venda não-só à maconha como a outras drogas, dentre clas. atualmente, o F̂xtase, fora do contexto desta matéria.

A Polícia Federal brasileira é excelente pelo volume de trabalho que tem a desempenhar em todo o território do País e, estupefata, descobriu em outubro deste ano 
pontos de venda de drogas nos shoppings paulistanos. O fato é que esses locais, atualmente, têm sido a "praia": de jovens em encontros e desencontros com os seus pares.

Infelizmente não é um fato que se impõc a certos larcs e que se possa descartá-lo com facilidade, observando que a indulgência dos pais conduz a insegurança dos filhos. Trata-se de realidade desconfortável não-só ao âmbito familiar brasileiro como ao de qualquer outro fora do País.

Os pais não conhecem os efeitos benéficos da droga e conseqüentemente reforça ainda mais o ponto de vista do adolescente. Isso acarreta discussões ferrenhas dentro do lar com a premissa final de que sempre existe desvantagem para os adultos, especialmente quando estes venham a se calcar por meio de normas de racionalidade, o que acontece com grande parcela da classe média.

$O$ profissor Mauro Weintraub relata incisivamente no livro acima apontado que:

\begin{abstract}
L'ma discussão ponderada, que gire em tomo do que é razoável e do que $\dot{c}$ admissivel, transforma-se num jogo com cartas marcadas. Quando o filho aponta o desconhecimento dos pais. estes ficam embaraçados: se não sei do que estou falando, como justificar minha condenação?

O inesmo tipo de argumento, porém, é ineficaz quando os papéis se invertem e é o adolescente o acusado de desinformação. Para este, a falta de conhecimentos sobre a ação prejudicial da maconha não representa defeito sério, pois ele conhece a euforia do 'barato', as gratificações psicológicas e sociais que seu consumo pode trazer.
\end{abstract}

Sendo assim. psicólogos, seguindo pesquisas realizadas, orientam os pais quando descobrem que o filho possui o hábito de fumar maconha a se comportar com cautela, tratando-o com o mesmo carinho anterior e a se aproximar ainda mais do adolescente para o diálogo; se possível totalmente informal.

$O$ informal se traduz por convergir a temas versáteis e gradativamente a se chegar ao tabaco e, por último, à maconha. Um álibi é o dos pais fumantes de tabaco que possuem, individualmente. o pretexto ou a chance de demonstrar o quanto não foram prevenidos ou avisados não-só pelos próprios avós ou pela sociedade da maledicência do uso de cigarros.

Segundo o médico neozelandês David Fergusson. da Universidade de Otago, que coordenou o maior estudo no mundo sobre a relação de adolescentes e jovens com a maconha:

O fundamental é conhecer bem os filhos, para poder interpretar eventuais mudanças de comportamento. É comum 
associar desinteresse pelo estudo e tendência ao isolamentu a evidências de envolvimento com drogas.

Na capital da Nova Zelândia, Wellingthon, o professor Fergusson proferiu dezenas de conferências em escolas públicas, a convite do Governo do seu país, além de ter sido entrevistado por dezenas de jornalistas do mundo inteiro. uma vez ter estudado e pesquisado um assunto de importância internacional.

A antitese da exposição acima é relatada no filme nacional intitulado Bicho de Sete Cabeças, baseado no romance Canto dos Malditos, de Austregésilo Carrano e dirigido por Laís Bodanzky. O personagem do pai, no enredo da trama, tem como princípio imediato severa punição ao filho, internando-o em manicômio psiquiátrico, quando descobre que ele é usuário da maconha. Pai e fillho são interpretados por Othon Bastos e Rodrigo Santoro, respectivamente.

Não-só no Brasil como na maioria dos países globalizados, exceto raras exceções, o desemprego tem sido alarmante, atingindo aqui cerca de $57 \%$ dos jovens. Em junho de 2005. o Instituto Brasileiro de Geografia Estatística (IBGE) revelou que 2,5 milhões de pessoas estão desempregadas nas seis regiões metropolitanas do País, ou seja, quase $10 \%$ da população economicamente ativa. Em busca de ofertas de trabalho e do seguro-desemprego mais de 2 mil desempregados procuram todos os dias o Centro de Solidariedade ao Trabalhador na Capital de São Paulo, com ênfase aos jovens entre 18 e 24 anos.

É cristalino que os jovens estão perdidos e à procura de seu primeiro emprego. Hoje em dia não adianta alcançar a nota mínima para aprovação, em média de trinta/quarenta matérias, de uma grade de graduação de primeiro e segundo graus ou universitária, e concluir que um diploma resolverá a vida.

Não adianta mais saber $80 / 90 \%$ de determinada matéria acadêmica. Há a necessidade de se dominar $100 \%$ de algo que seja favorável e útil para os outros. As universidades têm formado uma série de alunos especialistas em coisa alguma. Por quế?

Porque elas produzem commodities, isto é, preferem formar gencralistas, bem mais em conta, em parâmetro com especialistas. Premissa final: generalista que não tenha especialidade não arranja nem o primeiro emprego.

E com certeza jovens que nem emprego os seus pais têm, nunca alcançarão posição digna e de cidadania. $\Lambda$ começar pelo perfil atual do País: a verdadeira mentora de crimus ilícitos é a classe política, a qual deveria ser exemplo à sociedade. E é ela que incutiu nos delinqüentes que até para roubar tem de ter estudo! 
Não se pode descartar esse fato social: a frustração desta camada etária é acentuada junto à fobia que é a do medo patológico de intensidade desproporcional ao possivel risco. Frustrados, buscam equilíbrio no sexo e nas drogas.

Os jovens procuram o básico dos Direitos Humanos: a liberdade. A liberdade é conquistada por meio de empregos. Não têm tido oportunidade e, assim. encontram vias cruéis e são tragados ao crime.

No Brasil, os morros de metrópoles com suas favelas têm apresentado quadros horripilantes que são fechados aos olhos da sociedade e, principalmente, à políticos. Os políticos, eleitos para o Congresso Nacional, estão totalmente despreocupados com os programas estabelecidos por seus partidos Ł/ou reivindicados pela sociedade. Eles têm de olhar para o lado da humanização; estão sumariamente alheios aos problemas do País e, convenhamos, doutrinariamente não estão vinculados a nada!

E nesses morros, com ênfase aos do Rio de Janeiro, temos visto menores, que deveriam estar nas escolas, e adolescentes à mercê do tráfico de drogas; que trocam o dia pela noite, assistindo traficantes que colocam armas de fogo pesadas em suas mãos e delegam tarefas nada confortáveis como, por exemplo, embalar pequenos pacotes de Cannahis sativa e outras drogas até a ser sentinela das bocas-de-fumo. E é cristalino que são meninos que atendem serviços delivery aos usuários que têm acesso ao disque-drogas.

Esses meninos adolescentes agem desta maneira, porque querem ajudar as mães. O pai ć uma espécie em extinção; o pai ausente. A maioria deles não tem pai, ou é órfão, porque foram abandonados por eles ou porque o lado paternal desapareceu na guerra do tráfico. Como, também, porque seus pais pertencem, ou pertunceram, a facções criminosas com táticas de guerrilha e logística sofisticada que cada vez mais tem o poder vigoroso e forte em parâmetro à Polícia que, gradativamente, está enfraquecida. Enfraquecida, porque não há investimento algum em suas instituições. No País falta poder de decisão, vontade política de mudança. Aliás esse método não se negocia e sim se impõe. Finalizando, acentuada parcela desses menores terá o mesmo destino de scus pais. Trata-se de um problema social nacional que tem de ser repensado com urgência não-só pelos Governos Federal, Estadual e Municipal como por toda a sociedade inclusas as Organizações Não-Governamentais, CNBB e outras. O problema é gravíssimo, enquanto o País está aos poucos desmoronando moralmente!

c) Legalização ou-não da maconha?

O professor doutor David Teixeira de Azevedo, do Departamento de Direito Penal e Medicina Legal da Faculdade de Direito da Universidade de São Paulo, é 
favorável à descriminalização das denominadas drogas leves, inclusa e, principalmente, a maconha.

Segundo o ilustre e conceituado professor da Academia de Direito,

a droga adiç̧ão é antes de tudo uma doença e, como tal, necessita de compreensão e tratamento. A incriminação penal leva à marginalização do usuário que, por sua vez. utiliza contatos escusos e na ambiência da delinqüência para obtenção da droga. Não se pode dizer que a utilização de uma droga leve atinja o bem juridico tutelado que é, segundo nosso sistema penal, a saúde pública.

E acrescenta, de maneira enfática:

Há uma série de danos paralelos à criminalização do porte de entorpecentes para o uso próprio: a marginalização; o estigma criminal decorrente da persecução criminal: o aumento do consumo de entorpecentes ou, então, sua manutenção nos mesmos niveis caso não houvesse a proibição (o que é proibido ḋ sedutor); o desvio da responsabilidade estatal de assistência médica e social ao dependente para uma ação meramente repressiva.

Concluindo e acrescentando sobre outros argumentos favoráveis à descriminalização, o professor criminalista internacional Teixeira de Azevedo diz:

Cito, ainda como exemplo, a orientação politico-criminal do Direito Penal em um Estado Democrático de Direito, a qual não deve se voltar a aspectos ético-pessoais e existenciais, mas sim para 'manter de pé' uma sociedade imperfeita de homens imperfeitos. 5

O professor doutor Luiz Sergio Modesto, especializado em Teoria do Estado, de Ciência Política e de Filosofia do Direito teve pedras no caminho ao defender sua tese de doutorado intitulada As Drogas do Estado, na Faculdade de Direito da Universidade de São Paulo, em 1995. Um assunto polêmico para uma Faculdade de Direito. Baseado em sua tese vencedora, escreveu e participou de muitos livros sobre o assunto incluso o de autoria de Myltainho Severiano da Silva, que compõe a bibliografia deste trabalho.

O especialista Luiz Modesto assevera que o termo " droga" que tem como significado etimológico a expressão " folha seca" deixou de ter utilidade médica e cientifica para acentuar uma instrumentalidadu política de exclusão. Para ele, um caso

Entrevista dada ao Autor pelo eminente professor doutor David Teixeiru de Azevedo em 08 de novembro de 2005. 
exemplar é o dos FUA que acolhem as anfetaminas, o álcool mas recusam a Cannabis sativa.

E complementa:

Os cigarros de tabaco, produto que tem o Brasil como seu maior exportador mundial devem ser controlados como a morfina e a heroína pela Associação Médica Americana. Nesse contexto, a 'droga' tabaco, no entanto, adorna as Armas Nacionais da República Federativa do Brasil, ao lado da 'droga' café, respectivamente à esquerda e à direita da estrela de cinco pontas do símbolo, conforme legislação que associou a coletividade-Estado Brasil a estes alter-mentes, o Decreto n. 04, de 19 de novembro de 1889.

$\mathrm{Na}$ Classificação Internacional de Doenças (CID-10), documento cuja revisão periódica é coordenada pela Organização Mundial de Saúde, e que integra o nosso direito interno, contudo. o álcool, a Cannabis. a cocaína, o café e o tabaco, independentemente do critério lícito/ilicito, cada qual possivel de gerar dependência. Para me desvencilhar desse uso não-científico do signo, portanto, valho-me do termo alter-mente, termo inclusivo para 'droga', para medicamento e. numa perspectiva do gosto pessoal e plural, para o prazer no extracotidiano, item excluido no conceito de saúde da Organização Mundial de Saúde.

O termo alter-mente, conseqüentemente, escapa dessa polarização trazida por seu uso político, para a pluralização verificada pela Antropolugia no decorrer da História Humana. O controle da produção, distribuição e uso de altermente, que se convencionou demonizar no signo 'drogas', está atualmente com a Organização das Nações Unidas, ONL, por meio da Organização Mundial da Saúde, OMS. Este controle da ONU sobre os alter-mentes é feito pela Convenção Única sobre Entorpecentes, de 196I, pelo Protocolo de Emendas à Convenção Única sobre Entorpecentes, de 1972, e pela Convenção contra o Tráfico llícito de Entorpecentes e Substâncias Psicotrópicas, de 1988.

Essas normas estabelecem definiçõus absolutas sobre bases culturalmente ambiguas, reservas de mercado, tipos penais. sançôes, confiscos e extradições referentes ao plantio, à produção e ao consumo dc alter-mentes, sem respeitar os interesses das coletividades consumidoras dos Estadosmembros da ONU, incluidas as minorias habituais. Este último documento chega a prescrever a violência ecológica na erradicação da coca. em função da cocaina. mas não da cana, em função do álcool; prescreve a erradicação da Cannabis sativa, mas não do tabaco; prescreve a erradicação 
do ópio, mas não do café, como apontamus, todos catalogados como 'drogas'. Por çuê?

A premissa final do professor Modestn é a seguinte "o Brasil é o maior. exportador mundial de tubaco e café. Na classificação Internacional de Doenças, encontra-se na mesma página álcool, opiáceos, canabinóides, sedativos, cocaina, cafeina, alucinógenos, fumo, solventes, todos classificados como "droga" Se é para ser coerente, então vamos proibir tudo!"

O ilustre professor Luiz Modesto ainda elaborou uma série de pesquisas. das quais extraio uma única que, por sua vez, atende a apreciação correta e ao encontro desta exposição redatorial:

Pesquisa Americana ("Após descriminação, jovem não fuma mais. Nem menos. Continua fumando igual").

E relata breve comentário, a saber:

Entre 1975 e 1980, dez dos cinqüenta Estados norteamericanos tomaram a iniciativa de descriminar a maconha. O Instituto de Pesquisa Social da Universidade de Michigan, EUA, acompanhou a experiência e a publicou cm 1981. Os pesquisadores usaram, como fontes, veteranos e formandos de escolas supcriores naquele periodo. Um trecho fundamental da conclusão desse estudo é o transcrito a seguir:

'Sobretudo, a preponderância da evidência qui nós reunimos e examinamos aponta para a conclusão de que a descriminação realmente nào produziu e ceito algum sobre o uso da macunha, nem sobre atitudes relacionadas e conviç̧ões sobre o uso de maconha entre a juventude americana nessa faixa de idade'

Em pleno século XXI a Cannabis sativa continua a ser proibida, o usuário continua sujeito a processos e à prisão. O que se deve seguir é a criação de mecanismos, isto é, entrelaçamento minucioso entre a educação, a saúde e a assistência social.

O Código Penal não prccisa sofrer alteração substancial no capítulo do combate ao usuário da maconha. Inicialmunte tem de ser aprovado, com absoluta urgência, o uso terapêutico desta erva erroneamente condenada.

Por quê? Porque não tem o menor cabimento ou justificativa a proibição de determinada droga por causar efeitos negativos em pequena parcela de seus usuários e que

6 Seguindo orientação do professor doutor Luiz Scrgio Modesto, acolhemos o seguinte dado: "atualmente nos EUA, em I/ Estados o consumo da Camnabis sativa é permitido, ainda que o discurso central da Federação seja contra. Os EUA financiaram a erradicação de Cannabis no Mexxico e hoje aqueles Fstados americanos sāo grandes exportadores mundiais to produto: tomaram o mercado do México" 
seja insensivel à pequena minoria que, com certeza, tenha beneficios, enfatizando us soropositivos.

E é totalmente injustificável que o uso industrial da maconha continue proibido, uma vez o Ministério da Agricultura ter de estabelecer normas rígidas para que só sejam aprovadas sementes que possuam nenhum potencial psicoativo.

Há necessidade urgente de educação e informação sobre a maconha. Com todo o respeito à Polícia das três esferas. não são os policiais, qui ministram aulas em escolas públicas e privadas, que dissertarão corretamente o perfil da erva que tem o potencial medicinal ignorado.

Embora policiais qualificados, essas aulas convergem estritamente para o lado criminal, obtendo um saldo desfavorável para o aluno, uma vez acreditar que quem fuma maconha é bandido, marginal e que a maconha é a maior assassina da história da Botânica. Também como não se enquadra a idéia de intelectuais superesclarecidos ministrando esses conhecimentos, porque não faz o menor sentido, é até perigoso.

A estratégia seria a criação de cursos especializados em drogas em geral, integrados à grade de níveis secundários como Biologia, Botânica e/ou Conhecimentos Gerais, com professores devidamente esclarecidos. E neste contexto, temas inseridos sobre os efeitos da maconha, determinativos e de maneira realista, não de cunho voltado ao terrorismo. Desaconselhar o seu uso mas, e principalmente, difundir a informação.

Acredito que cada vez. mais esta conduta diminuiria a marginalização do usuário como, também, a rejeição da população. E a extirpação de menores em morros das metrópoles manipulando o tráfico de drogas. Nesse caso, a necessidade de haver mais acúmulo de conhecimento. Não há conhecimentô da porcentagem da população carcerária restrita de liberdade por motivo da (annubis sativa; não há dados sobre o perfil deste usuário e nos mesmos moldes ao de qualquer cidadão que porventura tenha esse hábito.

Aliás, no País, as estatísticas não são aplicadas em absolutamente nada. exceto as destinadas a assuntos políticos. A Urganização das Nações Unidas (ONU), em sctembro deste ano, reivindicou do Governo brasilciro a computação de quantos adolescentes têm vivido nas ruas das grandes cidades. Nenhum dado estatístico estava pronto para atendê-la. Os jornalistas sofrem para obter dados concretos; todavia, têm a capacidade de elaborar matérias que mostram a realidade brasileira, chegando, inclusive e corajosamente, a adentrar os morros, na expectativa de devolver menores às mães, à família. Trabalho a ser desenvolvido pela Administração Pública com mais freqüência e entusiasmo. 
Nas escolas, nunca se soube de pesquisa acompanhada de relatórios sobre o perfil do estudante que fuma maconha para posterior avaliação de seu desempenho escolar e profissional. Sendo assim, há de se realizar um esforço de pesquisas para se descobrir elementos a usses temas e, com isso. eliminar o conceito de que a maconha é uma erva do Diabo!

Lembremos que grandes potências européias como a Holanda. Suiça, Itália. Espanha e Luxemburgo tiveram experiências de descriminalização da maconha, cujos resultados em primeiros mesés demonstraram que o número de usuários nunca aumentou como, também, deixar de processá-los não implicou em momento algum em aumento no consumo. E como premissa maior: norma proibitiva não ajuda a conter o uso.

Em um cômputo geral a descriminalização só teria vantagens: economia no custo de processos e prisões, mais energia da Polícia enveredada a crimes mais graves, o término da marginalização dos usuários, diminuição do apartheid social, aumento da confiança da população em suas leis e na Polícia e, finalmente, uma maior abertura do debate sobre o assunto. conforme acima referido.

Mas a descriminalização não-interfere na parte principal do problema: o tráfico. O tráfico atual é muito violento e poderoso e é bom ressaltar que o tráfíco mais notório é o da cocaína, embora legalizar a Cannabis sativa não acabaria de fato com o problema em si, todavia em muito o reduziria.

Por outro lado, agricultores deveriam ser credenciados para plantação de quantidade pequena, tendo, inclusive, o Estado como intermediador e em parceria com o Ministério da Agricultura na cobrança de impostos, tendo como parâmetro o valor aproximado por grama, que atualmente deva estar entre $\mathrm{R} \$ 5$ e $\mathrm{R} \$ 10$.

Esse controle de impostos tem de ser sempre reavaliado, uma vez elevar-se o preço da grama, dar-se-á margem à abertura e continuidade do mercado negro, aliás o verificado no tabagismo de hoje em dia. Trata-se de um modelo com leis restritivas que faria com que o consumo de drogas pesadas diminuísse assustadoramente.

$O$ aumento da arrecadação seria monstruoso; todavia, não muito maior quanto à legalização total como acontece em determinados paises europeus. F. a legalização apresentada nustes moldes só seria praticável mediante negociação diplomática que, por sua vez, gerariam protestos de paises como os EUA. Mas, convenhamos, o panorama internacional está cada vez mais propenso a ousadias deste comportamento e certamente com o apoio europeu da ONU.

São Paulo, fevereiro de 2005. (Atualizada em novembro de 2005). 
10. Apêndice legislativa

- Decreto-Lei n. 891, de 25 de novembro de 1938 (Aprova a Lei de Fiscalização de Entorpecentes);

- Decreto-Lei n. 2.375, de 08 de julho de 1940 (Altera o Decreto-Lei n. 89I, de 25 de novembro de 1938):

- Decreto-Lei n. 3.114, de 13 de março de 1941 (Dispõe sobre fiscalização de entorpecentes);

- Decreto n. 54.216, de 27 de agosto de 1964 (Promulga a Convenção Unica sobre Entorpecentes);

- Lei n. 5.726, de 29 de outubro de 1971 (Dispõe sobre medidas preventivas e repressivas ao tráfico e uso de substâncias entorpecentes ou que determinem dependência física ou psíquica e dá outras providências);

- Portaria n. 18, de 28 de setembro de 1975 (Baixa instruções relativas à fiscalização e ao controle das substâncias que determinam dependência física ou psíquica e das especialidades que as contenham);

- Decreto n. 76.248, de 12 de setembro de 1975 (Promulga o Protocolo de Emendas à Convenção Única entre Entorpecentes de 1961);

- Lei n. 6.368, de 21 de outubro de 1976 (Dispõe sobre medidas de prevenção e repressão ao tráfico ilícito e uso indevido de substâncias entorpecentes ou que determinem dependência física ou psíquica e dá outras providências);

- Decreto n. 79.388, de 14 de março de 1977 (Promulga a Convenção sobre Substâncias Psicotrópicas);

- Decreto n. 79.455, de 30 de março de 1977 (Promulga o Acordo Sul-Americano de Entorpecentes e Psicotrópicos);

- Portaria n. 20, de 06 de setembro de 1977 (Baixa instruções sobre proibição, limitação e controle da produção, do controle e do uso de substâncias que determinem dependência física ou psíquica e medicamentos que as contenham);

- Decreto n. 85.110, de 02 de setembro de 1980 (Institui o Sisterma Nacional de Prevenção, Fiscalização e Repressão de Entorpecentes). 


\section{Referências}

BARRETO, João de Deus Lacerda Menna. A l.ei Antiróxicos comentada. Rio de Janeiro: Fditora Renes. 1972.

BARRETO, João de Deus I acerda Menna. Lei de Tóxicos, Jurisprudência comentada em nivel nacional. São Paulo: Freitas Bastos Editora, 1974.

BONNET, Emilio Federico Pablo. Medicina Legal. Buenos Aires: Lopez Libreros Editores S.R.L., 1967.

BURGIERMAN, Denis Russo. Maconha. São Paulo: Editora Abril. 2002.

BUZZO, Alfredo; SORIA, Miguel Fernando. Toxicologia. Buenos Aires: Editora Lopes Libreros, 1966.

COSTA JUNIOR. João Baptista de Oliveira. Medicina Legal. São Paulo: Editora Brasiliense, 1970.

FERGUSSON, David. Maconha, é droga, sim. VEJA, p. 11-15, 21.09.2005.

FREIRE, Gilberto de Melo. O Escravo nos Anúncios de Jornais Brasileiros do Século XIX. Extraido por compilação do Serviço de Documentação da Biblioteca Nacional do Rio de Janeiro. Rio de Janeiro: Biblioteca Nacional, 2002.

GABEIRA, Fernando. A Maconha. Folha Explica, Publifolha, São Paulo, 2000.

GOMES, Geraldo. Os .4lucinógenos e o Direito. São Paulo: Editora Juriscredi, 1972.

GONZAGA. João Bernardino. Entorpecentes. São Paulo: Editora Max Limonad, 1965.

GRECO FILHO, Vicente. Tóxicos. São Paulo: Saraiva. 1980.

HERNMAN, Anthony; PESSOA JUNIOR, Osvaldo. Diamba Sarabamba. Coletânea de textos brasileiros sobre a maconha. Ground: EDS, 1986.

IOSCHPE, Gustavo. A ignorância custa um mundo. Porto Alegre: Editora Francis, 2005.

KANITZ, Stephen. Ponto de Vista. VEJA Colunista, filósofo e administrador da Universidade Harvard, p. 20; 06.08.2005.

MARANHÃO, Odon Ramos. Intoxicação por Maconha. Revista da Faculdade de Direito da Universidade de São Paulo. São Paulo, v. 83. p. 101-108. jan.idez. 1988.

MÉDICI, Sérgio de Oliveira. Tóxicos: doutrina, prática, jurisprudência, legislação. Bauru: Editora Jalovi. 1982. 
MIRANDA, Sandra Julien. (Org. e Coord.). Tráfico de entorpecentes. São Paulo: Editora Rideel Ltda., 1999.

MODESTO, Luiz Sergio. As Drogas do Estado; entrevista ao Onze de Agôsı. órgão informativo dos alunos da Faculdade de Direito da USP, n. I, p. 5-8, DCI Editora Jornalística, São Paulo, 1995.

MODESTO, Luiz. Sergio. Fenomenologia das Coletividades Familia. Bando, Estado. As Drogas do Estado. Revista Paradigma, Ciências Juridicas, v. 8, n. 8, 1998, p. 59-68, 1997.

MODESTO, Luiz Sergio. ONU: fundamentalismo puritano no mercado. In: RIBEIRO, Maurides de Melo; SElBEL, Sérgio Dario. (Orgs.). Drogas: a hegemonia do cinismo. Memorial. Săo Paulo: Fundação Memorial da América Latina, 1997. p. 91-104.

RODRIGUES. Thiago Moreira de Souza. Politica e Drogas nas Américas. São Paulo: EDUC, 2003. ROSADO, Pedro Nicolau Gonçalves Santos. Estudo dos Distúrbios Nervosos Produzidos pelo uso da Maconha. In: MACONHi1. Colelânea de Trabalhos Brasilciros. Rio de Janeiro: 1958. p. 365366 .

SILVA, Myltainho Severiano da. Se Liga! O Livro das Drogas. 3. ed. Rio de Ianeiro/São Paulo: Fditora Record, 1997.

SILVEIRA, Alipio. Prisão Albergue São Paulo: Brasilivros Fditora e Distribuidora, 1981. v. II.

SZNICK, Valdir. Entorpecentes. São Paulo: Sugestões Literárias, 1981.

TEIXEIRA, Ib. Fscândalo: maconha foi legalizada! FOLHA UNIVERSAL, Caderno 02, n. 598, 21 a 27.09.2003.

VERGARA, Rodrigo. Drogas. São Paulo: Editora Abril. 2003.

WEINTRAUB, Mauro. Sonhos e Sombras. A Realidade da Maconha. São Paulo: I:ditora Harper \& Row do Brasil Ltda, 1983. 